\title{
Temporal variations in suspended particulate waste concentrations at open-water fish farms in Canada and Norway
}

\author{
Lindsay M. Brager ${ }^{1}$, Peter J. Cranford ${ }^{1, *}$, Henrice Jansen ${ }^{2}$, Øivind Strand ${ }^{3}$ \\ ${ }^{1}$ Department of Fisheries and Oceans, Bedford Institute of Oceanography, 1 Challenger Drive, Dartmouth, \\ Nova Scotia B2Y 4A2, Canada
}

${ }^{2}$ Wageningen IMARES-Institute for Marine Resources and Ecosystem Studies, Korringaweg 5, 4401 NT Yerseke, The Netherlands ${ }^{3}$ Institute of Marine Research, Nordnesgaten 50, 5005 Bergen, Norway

\begin{abstract}
The co-cultivation of finfish and bivalve filter feeders, with the purpose of recycling solid waste effluents and enhancing aquaculture revenues, has stimulated efforts to characterize particulate waste dynamics at open-water fish farms. Temporal variability in waste concentrations in the water column was studied at Atlantic salmon Salmo salar farms in eastern Canada and Norway, and at a sablefish Anoplopoma fimbria farm in western Canada. Turbidity and chlorophyll a (chl a) sensors were used to continuously monitor suspended particulate matter (SPM) and chl a concentrations at various depths and distances to the net-pens. Time-series analysis of these data indicated that SPM fluctuations at the study sites corresponded largely with tidal periodicity and variations in phytoplankton biomass ( $\mathrm{chl}$ a). ANOVA comparisons of mean SPM levels in water flowing from the direction of net-pens (potential farm influence) and towards the farm (control) generally indicated insignificant effects of fish wastes on SPM levels at the farms ( $p>0.05)$. A significant effect of the farm was detected by an ANOVA comparison of SPM concentrations collected at $5 \mathrm{~m}$ depth at farm and reference stations in an oligotrophic fjord, but the calculated level of waste enhancement over the sampling period was extremely small $\left(0.02 \mathrm{mg} \mathrm{l}^{-1}\right)$. Results indicate that temporal variations in SPM concentrations around the open-water fish farms were largely driven by natural processes and that the addition of fish wastes had a negligible effect. Consequently, there is little rationale for introducing commercial extractive species (e.g. bivalves) in open-water integrated multi-trophic aquaculture systems to mitigate the horizontal flux of particulate fish wastes.
\end{abstract}

KEY WORDS: Aquaculture wastes $\cdot$ Suspended particulate matter $\cdot$ Integrated multi-trophic aquaculture $\cdot$ Salmo salar $\cdot$ Anoplopoma fimbria

\section{INTRODUCTION}

Aquaculture has been responsible for the continuing growth in global fish production since capture production levelled off in the mid-1990s. Global aquaculture is the fastest growing food-producing sector, with nearly half of the world's seafood supply now sourced from aquaculture (FAO 2012). A main

*Corresponding author: peter.cranford@dfo-mpo.gc.ca challenge facing this industry is sustaining a continued increase in fish production while minimizing the impact on the environment (Sugiura et al. 2006, Navarrete-Mier et al. 2010, Taranger et al. 2015). The open nature of many fish culture systems allows for continuous exchange of water between the cages and the surroundings (Beveridge 1984, Gowen \& Bradbury 1987, Folke \& Kautsky 1989, Beveridge et Access under Creative Commons by Atribution Licence. Use, distribution and reproduction are unrestricted. Authors and original publication must be credited.

Publisher: Inter-Research · www.int-res.com 
al. 1991, 1994, Phillips et al. 1991) and the rapid expansion of caged fish culture has raised a general concern about the release of solid and dissolved waste products to the environment (Troell \& Norberg 1998, Perez et al. 2002, Cheshuk et al. 2003, Whitmarsh et al. 2006, Valdemarsen et al. 2012, Taranger et al. 2015). Conspicuous environmental effects can stem from the increased organic matter loading on the seafloor, and consequential changes in benthic habitat and communities (Strain \& Hargrave 2005, Kutti et al. 2007). Large faecal particles and uneaten feed sink rapidly and accumulate in sediments below and within the vicinity of the net-pens (Cromey et al. 2002, Olsen et al. 2008, Nickell et al. 2009). Fine waste particles can remain in suspension for long periods and there is some evidence that suspended particulate matter (SPM) levels are enhanced in waters adjacent to fish farms (Jones \& Iwama 1991, Lefebvre et al. 2000, MacDonald et al. 2011, Lander et al. 2013, Brager et al. 2015, Bannister et al. 2016). However, particle enhancement around fish pens has not been consistently observed (Buschmann et al. 1996, Pridmore \& Rutherford 1992, Lander et al. 2013, Brager et al. 2015) and the reasons for these different conclusions on waste enhancement of the natural particle field are not fully understood.

Integrated multi-trophic aquaculture (IMTA) involves the co-culture of several commercial species in a system designed to facilitate the conversion of wastes produced at each trophic level into additional aquaculture revenue (Chopin et al. 2001, Troell et al. 2003). Open-water IMTA systems generally include the primary finfish component, a dissolved inorganic waste extractive component, such as seaweeds, and filter- and/or deposit-feeding species to capture, assimilate and extract particulate organic wastes. IMTA has been practiced for centuries in Asia (Li 1987, Fang et al. 1996, Qian et al. 1996), and the cultivation of scallops, kelp and abalone in Sungo Bay, China, has been commercially successful at industrial scales (Fang et al. 1996, Troell et al. 2009). IMTA has more recently been explored in Canada, Scotland, Australia and Norway, where several pilot experiments have been conducted (Stirling \& Okumus 1995, Cheshuk et al. 2003, Chopin et al. 2001, Handå et al. 2012a, 2012b). Development of the particulate organic extractive component of IMTA has largely focused on the introduction of filter-feeding bivalve molluscs inside and/or adjacent to fish net-pens (Soto 2009). However, the expected enhancement of bivalve growth in polyculture and IMTA systems has not consistently been realized (Jones \& Iwama 1991, Taylor et al. 1992, Stirling \& Okumus 1995, Gryska et al. 1996, Cheshuk et al. 2003, Lander et al. 2004, Sarà et al. 2009, Navarrete-Mier et al. 2010, Handå et al. 2012a, Lander et al. 2012, Jiang et al. 2013). The effectiveness of bivalves to extract fish wastes under open-water conditions also appears to be much lower than anticipated (Troell \& Norberg 1998, Cranford et al. 2013). Improving interactions between fish wastes and extractive species through refinements in IMTA system design may be expected to improve crop yields and the intended ecological benefits of the IMTA approach. However, this optimization of farm design requires knowledge on particulate waste dynamics and transport pathways under relevant hydrographic conditions.

Lander et al. (2013) examined the characteristics of suspended particles released from salmon farms and concluded that particle concentrations within $5 \mathrm{~m}$ of fish cages are significantly enhanced with highly organic particles over the long term, and that reliable pulses of this material exits fish farms in the upper water column over daily feeding cycles. Brager et al. (2015) expanded on this work by conducting highresolution 3-D spatial surveys of SPM concentrations around 4 fish farms in Canada. This latter study also showed that fish waste enhancement was highly localized, but concluded that there was no evidence of a waste plume from the net-pens and that natural seston patchiness can confound the identification of waste particle enhancement. Although these spatial surveys were conducted during fish feeding periods when particle concentrations have been reported to be elevated (e.g. Lander et al. 2013), any spatial sampling represents a snapshot in time and it is possible that the sampling periods did not coincide with the export of fish wastes. The present study expanded on these past studies by focusing on temporal variations in particulate waste concentrations adjacent to openwater fish net-pens. The primary objective was to quantify the contribution of particulate fish wastes to natural food resources available to filter feeders in IMTA systems. Open-water net-pen farms in Norway and Canada were selected for this research to include environments with different trophic states and ambient suspended particle characteristics. The Norwegian sites are characterized as oligotrophic environments with the seston dominated by phytoplankton, while the mesotrophic Canadian sites typically contain a more complex and variable particle regime. According to 2012 statistics, Norway and Canada contributed 79 and $3 \%$, respectively, of the $1.66 \mathrm{M}$ tonnes of cultured fish produced in the North Atlantic region (FAO 2012). 


\section{MATERIALS AND METHODS}

\section{Study sites}

Time-series data on suspended particle concentrations were collected at 5 fish farms (Fig. 1). On the Canadian east coast, field studies were conducted at 2 Atlantic salmon Salmo salar farms in the macrotidal Passamaquoddy Bay region of the Bay of Fundy: Navy Islands $\left(45^{\circ} 1.8^{\prime} \mathrm{N}, 67^{\circ} 0.3^{\prime} \mathrm{W}\right)$ and Charlie Cove $\left(45^{\circ} 1.8^{\prime} \mathrm{N}, 66^{\circ} 52.0^{\prime} \mathrm{W}\right)$. On the Canadian west coast,
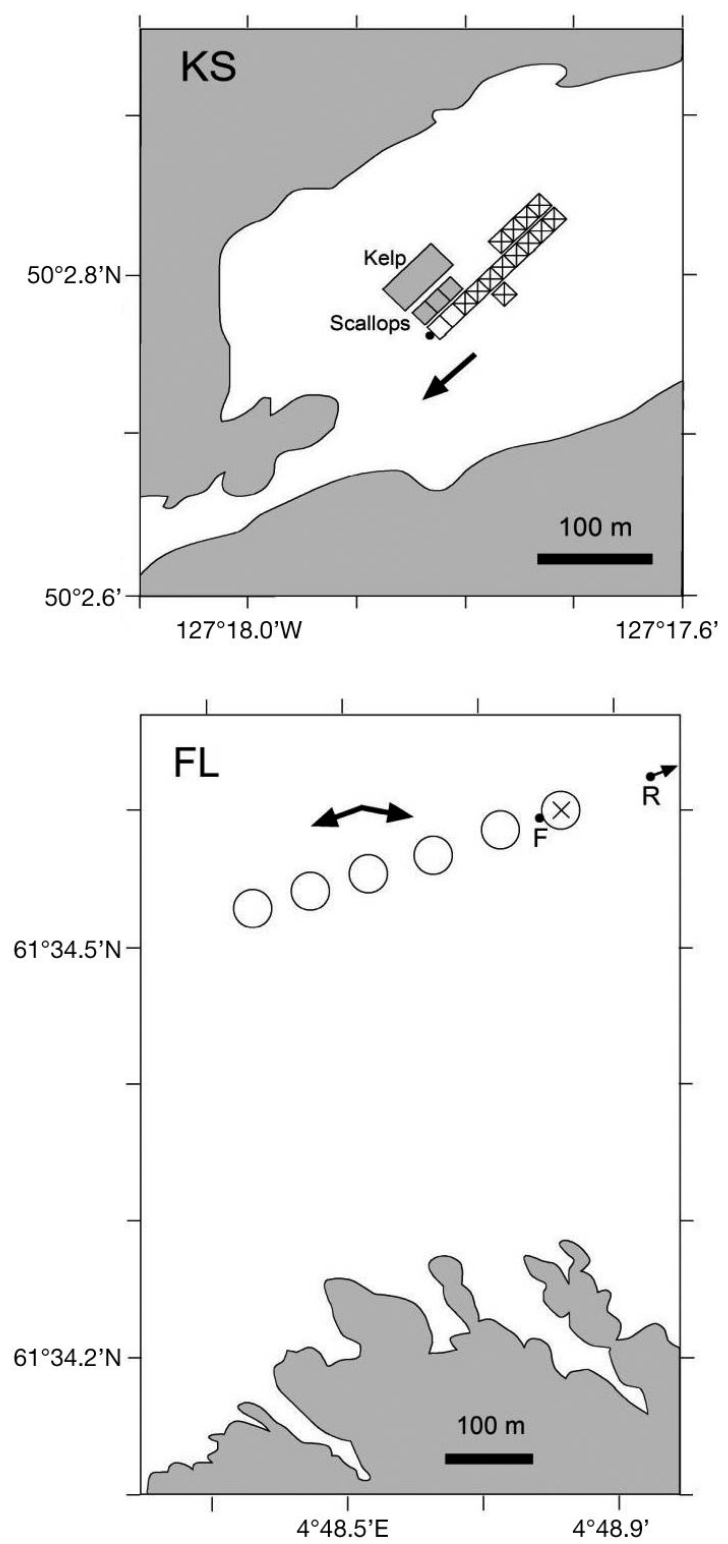

data were collected at a site culturing Anoplopoma fimbria (black cod) in Kyuquot Sound on the northwest coast of Vancouver Island $\left(50^{\circ} 2.8^{\prime} \mathrm{N}, 127^{\circ}\right.$ $\left.17.8^{\prime} \mathrm{W}\right)$. The Navy Islands site contained 15 circular net pens (25 m diameter), while the Charlie Cove and Kyuquot Sound farms had 8 (25 m diameter) and 2 (25 $\mathrm{m}$ square) stocked pens at the time of sampling, respectively. Both east coast sites (Navy Islands and Charlie Cove) are $23 \mathrm{~m}$ in depth, and subject to strong tidal currents and mixing owing to the $6 \mathrm{~m}$ average diurnal tidal range (Trites \& Garrett 1983,
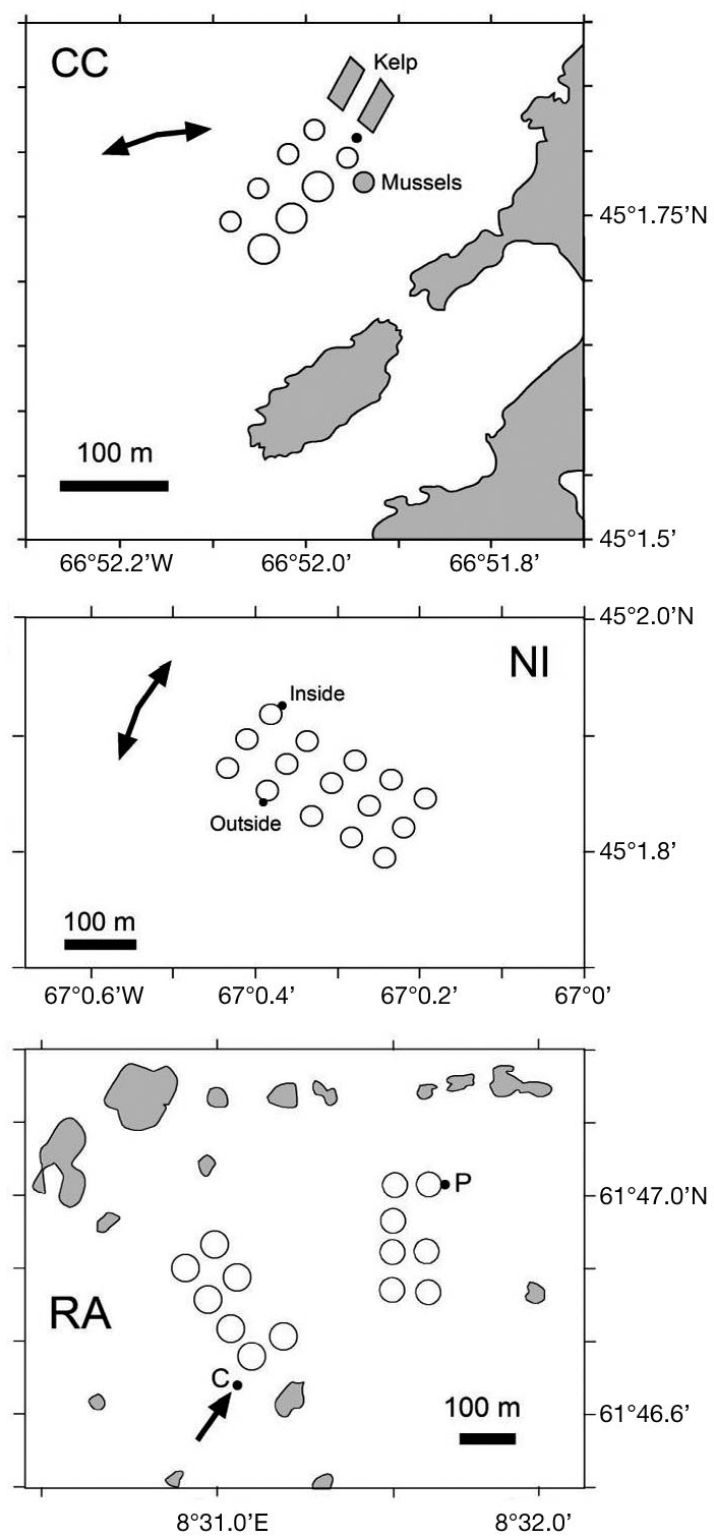

Fig. 1. Navy Islands (NI), Charlie Cove (CC) and Kyuquot Sound (KS) study sites in Canada, and the Rataran (RA) and Flåtegrunnen (FL) study sites in Norway. Fish net-pens are represented by open symbols; shaded symbols indicate net-pens for other taxa; closed circles show the locations of instrument moorings or profiling stations. Pens not containing fish are indicated by an ' $x$ '. The arrows show prevailing current directions during flood and ebb tides. The reference site (R) at the FL farm was located $1 \mathrm{~km}$ to the east of the farm site (F). Profiling (P) and current meter (C) locations are identified for the RA farm 
Thompson et al. 2002). The Kyuquot Sound site is approximately $28 \mathrm{~m}$ in depth, and subject to a $3 \mathrm{~m}$ average semi-diurnal tidal range. All Canadian sites contained fish in their final season of growth and feeding was underway during sampling periods. Each salmon cage is known to contain between 30000 to 50000 fish, giving a minimum of 450000 and 240000 fish at the Navy Islands and Charlie Cove farms, respectively. The Kyuquot Sound farm contained approximately 100000 fish of harvest size in 2 square steel frame net-pens. Other pens at this farm contained small quantities of scallops and kelp.

The 2 Atlantic salmon farms sampled in Norway were the Flåtegrunnen farm in the Florø area $\left(61^{\circ} 34.5^{\prime} \mathrm{N}, 4^{\circ} 48.6^{\prime} \mathrm{E}\right)$ and the Rataran farm in the Frøya area $\left(63^{\circ} 46.8^{\prime} N_{1} 8^{\circ} 31.0^{\prime} \mathrm{E}_{i}\right.$ Fig. 1$)$. The Flåtegrunnen farm was located in relatively deep water (75 to $200 \mathrm{~m}$ depth) and contained 8 circular pens (50 m diameter), with 7 pens containing fish. During the sampling period, the farm contained a total of 3050 tonnes of 13-mo-old salmon and feed was supplied at 20 tonnes per day. The Rataran farm contained 14 net-pens (50 m diameter), with each pen containing an average of 620 tonnes of 18-mo-old salmon. During sampling at this farm, feed was being pumped to the net-pens at 80 tonnes per day. The floating net-pens at the Canadian farms extended from the surface down to $15 \mathrm{~m}$ depth while the Norwegian net-pens were $25 \mathrm{~m}$ deep. All 5 fish farms studied were located at least $1 \mathrm{~km}$ away from other aquaculture activities.

\section{Particle-sensing instrumentation and experimental design}

Times-series of SPM were obtained using moored instruments or through repeated water column profiling at a set location. Particle sensors attached to moorings consisted of optical back-scatter (OBS) sensors and chlorophyll a (chl a) fluorometers (FLNTUSB ECOMeter, WET Labs). The OBS sensors provided information on total SPM concentrations, including both natural seston and particulate farm wastes, while the chl a fluorometers provided simultaneous data on phytoplankton biomass. Chl a was monitored to control for the potential influence of natural phytoplankton variations on SPM levels. The instruments contained internal batteries and a data logger for autonomous recording. For profiling purposes, a sensor platform was employed that consisted of a CTD (MicroCTD, AML Oceanographic), a chl a fluorometer (Cyclops 7, Turner Designs) and a transmis- someter with a $25 \mathrm{~cm}$ optical path length for measuring SPM concentrations (c-Rover CRV5, WET Labs). The instrument frame was designed to be compact and light for manual profiling operations, with the sensors encased within a streamlined polyethylene jacket that allowed water to flow past the instruments while preventing instrument entanglement with mooring ropes and nets. Current meters were deployed at each farm site.

A control/impact experimental design was utilized at each farm site, with the exception of Rataran (see below), to detect the presence of particulate farm wastes. However, results from previous studies on spatial variability in SPM levels at each farm dictated the use of 2 different approaches for detecting the presence of particulate fish wastes. Brager et al. (2015) showed that natural seston patchiness at the mesotrophic Canadian farm sites results in natural differences in SPM levels at potential reference and farm mooring sites that would confound the interpretation of any site comparisons. Consequently, sensor moorings were only located in the vicinity of the farms and the mean effect of waste effluents on particulate matter concentrations was assessed by comparing particle data from periods when the current at the mooring site was flowing towards the farm (reference condition with no farm influence) and from the direction of net-pens (potential SPM enhancement from farm wastes). Preliminary work at the Flåtegrunnen farm showed a highly uniform spatial distribution in SPM levels in this oligotrophic fjord (P. Cranford unpubl. data). Reference and farm mooring sites were therefore used for this site to detect the mean effect of farm wastes on particulate matter concentrations, in addition to the directional approach described above for the other farms.

At the Navy Islands farm, particle sensors were hung at $5 \mathrm{~m}$ depth from the side of fish cages on opposite sides of the farm (Fig. 1). These 2 mooring sites are referred to as the 'inside' and 'outside' moorings, which reflect their position relative to the direction of flood tide. Two acoustic Doppler velocimeters (Argonaut $\mathrm{ADV}_{\text {; }}$ SonTeK/YSI) were also attached to the same instrument frames to measure variations in current speed and direction. The instruments were programmed for burst sampling (1 Hz sampling for $10 \mathrm{~s}$ ) at 2 min intervals from 16 to 18 November 2010. Single moorings were deployed at the Charlie Cove and Kyuquot Sound farms. At Charlie Cove, the mooring was deployed $20 \mathrm{~m}$ away from a net-pen (Fig. 1) with ECOMeters attached at 5 and $15 \mathrm{~m}$ depth on the same mooring. An Infinity-EM current meter (JFE Advantech) was attached to the mooring at $1.5 \mathrm{~m}$ 
depth and an Argonaut ADV at $15 \mathrm{~m}$ depth. The $10 \mathrm{~s}$ instrument data bursts were recorded every $10 \mathrm{~min}$ between 5 and 15 July 2011. At Kyuquot Sound, the mooring was hung from the side of the net pen containing the largest number of fish (Fig. 1), with ECOMeters attached at 1 and $20 \mathrm{~m}$ depth and an Infinity current meter located at $19 \mathrm{~m}$. The $10 \mathrm{~s}$ data bursts were logged at 1 min intervals between 24 and 28 July 2011. Two moorings were deployed at the Flåtegrunnen farm (Fig. 1). An ECOMeter and an Infinity current meter were suspended at $5 \mathrm{~m}$ depth from the edge of an empty fish pen. This location was $50 \mathrm{~m}$ from the nearest pen containing fish. A second ECOMeter was deployed at the same depth at a site located $1000 \mathrm{~m}$ away (Fig. 1). The instruments at this site were programmed for $10 \mathrm{~s}$ data bursts every 5 min between 10 and 12 September 2013. For ease of reference, sensor deployment details for each farm are summarized in Table 1.

Water column profiling was conducted $2 \mathrm{~m}$ away from the side of a net-pen at the Rataran farm $\left(63^{\circ} 47.02^{\prime} \mathrm{N}, 8^{\circ} 31.69^{\prime} \mathrm{E}\right.$; Fig. 1). Temporal variations in SPM, chl $a$, salinity and temperature between 0.5 and $30 \mathrm{~m}$ depth were recorded by continuously lowering and raising the profiler while logging data at $1 \mathrm{~s}$ intervals using Windmill 7 data acquisition and visualization software (Windmill Software). Sampling was conducted between 13:38 and 15:00 h on 6 August 2014. During profiling operations, currents at $20 \mathrm{~m}$ depth were measured at 5 min intervals with an Aanderra ADCP current meter moored to the southwest of the farm (63 $46.74^{\prime} \mathrm{N}, 8^{\circ} 31.02^{\prime} \mathrm{E}$; Fig. 1).

The WET Labs ECOMeters and Cyclops fluorometer were calibrated in the laboratory using chl $a$ and total SPM standards $(\mathrm{n}=14)$. Standards were pre- pared by suspending known concentrations of algal cells (mixed flagellates) or fine sediment (natural clay/silt mixture pre-sieved through a $64 \mu \mathrm{m}$ mesh) in filtered $(0.45 \mu \mathrm{m})$ seawater. SPM and chl a concentrations in all standards were determined using routine gravimetric and fluorometric procedures as described in Brager et al. (2015). The c-Rover transmissometer was calibrated in the laboratory using ground fish feed standards $(\mathrm{n}=16)$ and under field conditions with natural seston samples collected in triplicate at the same depth as the cRover $(\mathrm{n}=101)$. The laboratory calibration was conducted to confirm sensor output linearity with a potential fish farm waste. However, the seston calibration was used for calculating SPM concentrations at the farm site. Comparisons of data obtained using the different SPM (ECOMeter and cRover) and chl a (ECOMeter and Cyclops) sensors were conducted under field conditions at the study sites to confirm that they provided comparable concentrations. All calibration equations and curve fit data are summarized in Table 2.

\section{Data analysis}

SPM $\left(\mathrm{mg} \mathrm{l}^{-1}\right)$ and $\mathrm{chl} \mathrm{a}\left(\mu \mathrm{g} \mathrm{l}^{-1}\right)$ data for each site were averaged to obtain a single value for each $10 \mathrm{~s}$ sample burst. No further data smoothing was performed prior to statistical analysis; however, a 3-sample running mean was used for plotting time-series data. Tidal elevation predictions for the Canadian farms were obtained for sampling periods using the WebTide tidal prediction model (version 7.0.1) developed by Fisheries and Oceans Canada (www.bio.gc.

Table 1. Deployment types at each location included fixed depth instrument moorings (number of mooring sites indicated) or water-column profiling. Details of particle and current meter sensor deployments at the 5 fish farms (see Fig. 1)

\begin{tabular}{|c|c|c|c|c|c|c|}
\hline Farm & Type (no.) & Dates & Instruments & $\begin{array}{l}\text { Distance } \\
\text { to pen }(\mathrm{m})\end{array}$ & $\begin{array}{l}\text { Depth } \\
\text { (m) }\end{array}$ & $\begin{array}{c}\text { Sampling } \\
\text { frequency (min) }\end{array}$ \\
\hline Navy Islands & Mooring (2) & 16-18 Nov 2010 & ECOMeter, Argonaut ADV & 1 & 5 & 2 \\
\hline Charlie Cove & Mooring (1) & 5-15 Jul 2011 & $\begin{array}{c}\text { ECOMeter } \\
\text { Infinity-EM } \\
\text { ECOMeter } \\
\text { Argonaut ADV }\end{array}$ & 20 & $\begin{array}{c}5 \\
1.5 \\
15 \\
15\end{array}$ & $\begin{array}{l}10 \\
10 \\
10 \\
10\end{array}$ \\
\hline Kyuquot & Mooring (1) & 24-28 Jul 2011 & $\begin{array}{c}\text { ECOMeter } \\
\text { Infinity-EM } \\
\text { ECOMeter }\end{array}$ & 1 & $\begin{array}{c}1 \\
19 \\
20\end{array}$ & $\begin{array}{l}1 \\
1 \\
1\end{array}$ \\
\hline Flåtegrunnen & Mooring (2) & 10-12 Sep 2013 & $\begin{array}{l}\text { ECOMeter } \\
\text { Infinity-EM } \\
\text { ECOMeter }\end{array}$ & $\begin{array}{c}50 \\
50 \\
1000\end{array}$ & $\begin{array}{l}5 \\
5 \\
5\end{array}$ & $\begin{array}{l}5 \\
5 \\
5\end{array}$ \\
\hline Rataran & Profiling & 6 Aug 2014 & Cyclops, cRover, MicroCTD & 2 & $1-30$ & $1 \mathrm{~s}$ \\
\hline Rataran & Mooring (1) & 4-15 Aug 2014 & Aanderra ADCP & 100 & 20 & 5 \\
\hline
\end{tabular}


Table 2. Results of regression analysis of suspended particulate matter (SPM) and chlorophyll a (chl a) instrument responses (counts or $\mathrm{mV}$ ) to calibration standards prepared as described in the 'Materials and methods'. SEE: standard error of estimate

\begin{tabular}{|c|c|c|c|c|c|}
\hline Parameter & Instrument & Equation & $\mathrm{r}^{2}$ & $\mathrm{p}$ & SEE \\
\hline \multirow[t]{4}{*}{$\mathrm{SPM}\left(\mathrm{mg} \mathrm{l}^{-1}\right)$} & ECOMeter 2018 & $\mathrm{SPM}=(0.005 \times$ counts $)+0.930$ & 0.998 & 0.0001 & 0.28 \\
\hline & ECOMeter 2017 & $\mathrm{SPM}=(0.004 \times$ counts $)+0.815$ & 0.997 & 0.0001 & 0.34 \\
\hline & cRover (seston) & $\mathrm{SPM}=-12.173 \times \ln ($ counts $)+18.439$ & 0.892 & 0.0001 & 1.80 \\
\hline & cRover (feed) & $\mathrm{SPM}=-15.911 \times \ln ($ counts $)+23.217$ & 0.999 & 0.0001 & 0.30 \\
\hline \multirow[t]{3}{*}{ Chl a $\left(\mu g \mathrm{l}^{-1}\right)$} & ECOMeter 2018 & Chl $a=(0.013 \times$ counts $)-2.949$ & 0.991 & 0.0045 & 0.25 \\
\hline & ECOMeter 2017 & Chl $a=(0.013 \times$ counts $)-2.949$ & 0.955 & 0.0041 & 0.26 \\
\hline & Cyclops 7 & Chl $a=(4.938 \times \mathrm{mV})-0.221$ & 0.999 & 0.0001 & 0.18 \\
\hline
\end{tabular}

$\mathrm{ca} /$ science/research-recherche/ocean/webtide/indexen.php). Tidal elevation measurements from monitoring stations located near the Norway farms were obtained from the Norwegian Hydrographic Service (Norwegian Mapping Authority). Spectral analysis was conducted on the SPM time-series data to identify any regularly repeating patterns. All SPM data were linearly detrended prior to using the periodogram function of MATLAB. Cyclic periodicities were obtained from peak periods (hour) in the periodogram plots. Contour plots of chl $a$ and SPM concentrations measured at the Rataran farm were produced with Surfer 9 software (Golden Software) using the ordinary kriging interpolation method.

Hypotheses on the potential enhancement of SPM concentrations with particulate wastes from fish netpens at each sampling location were tested using one-way ANOVA (Systat version 13, SPSS). SPM data collected at single mooring locations were pooled by current direction, with 12 direction levels representing $30^{\circ}$ compass bearing increments. The hypothesis tested was that mean SPM concentrations were equal for all flow directions. The alternate hypothesis was accepted if the $p$-value was $\leq 0.05$. In the event of a significant effect, a single Tukey post hoc comparison was performed comparing differences in mean SPM levels in water flowing to the sampling site directly from the farm and from the opposite direction. SPM enhancement with waste particles was calculated from differences in mean SPM concentrations for these same 2 groups of pooled data (mean SPM from direction of farm minus mean SPM in water flowing towards the farm). Data collected at the Flåtegrunnen salmon farm included sampling locations near the farm $(50 \mathrm{~m})$ and at a reference site located $1 \mathrm{~km}$ away. SPM concentrations measured at $5 \mathrm{~m}$ depth at both locations were compared using ANOVA, and the degree of SPM enhancement was calculated from the difference in mean concentrations. Prior to performing each ANOVA, the data were screened for normality and homoscedasticity by examining normal probability and residual plots. The independence assumption was tested based on calculation of the Durbin-Watson $D$-statistic and the first-order autocorrelation. The results of statistical tests were only reported when these assumptions were not violated.

\section{RESULTS}

\section{Moored instruments}

Time series of SPM and chl a concentrations and current speed data for the different mooring locations and fish farms are shown in Figs. 2 to 5. Mean $( \pm$ SD) SPM concentrations measured at $5 \mathrm{~m}$ depth on the inner- and outer-bay sides of the Navy Islands farm were equal $\left(2.4 \pm 0.2 \mathrm{mg} \mathrm{l}^{-1}\right.$ for both sites $)$ and displayed similar temporal variability (Fig. 2). Relatively high winds on the afternoon of 17 November (data from Environment Canada), which reached $25 \mathrm{~km} \mathrm{~h}^{-1}$, preceded peaks in current speed and SPM and chl $a$. Chl a and SPM concentrations were not correlated at this site $\left(r^{2}=0.01\right)$. Predominant current directions at both locations were $35^{\circ}$ and $200^{\circ}$ on the flood and ebb tide, respectively. Although data collection was limited to 4 tidal cycles, spectral analysis indicated $12.3 \mathrm{~h}$ periodicity in SPM at this farm. ANOVA indicated a significant effect of current direction on mean SPM concentrations at both the inside and outside mooring locations (Table 3). However, Tukey post hoc comparisons showed no significant difference in SPM concentrations in water flowing from the direction of the net-pens, compared with water flowing from the opposite direction (Table 3).

Measurements made at 2 depths over a $10 \mathrm{~d}$ period at the Charlie Cove farm showed temporal variability 

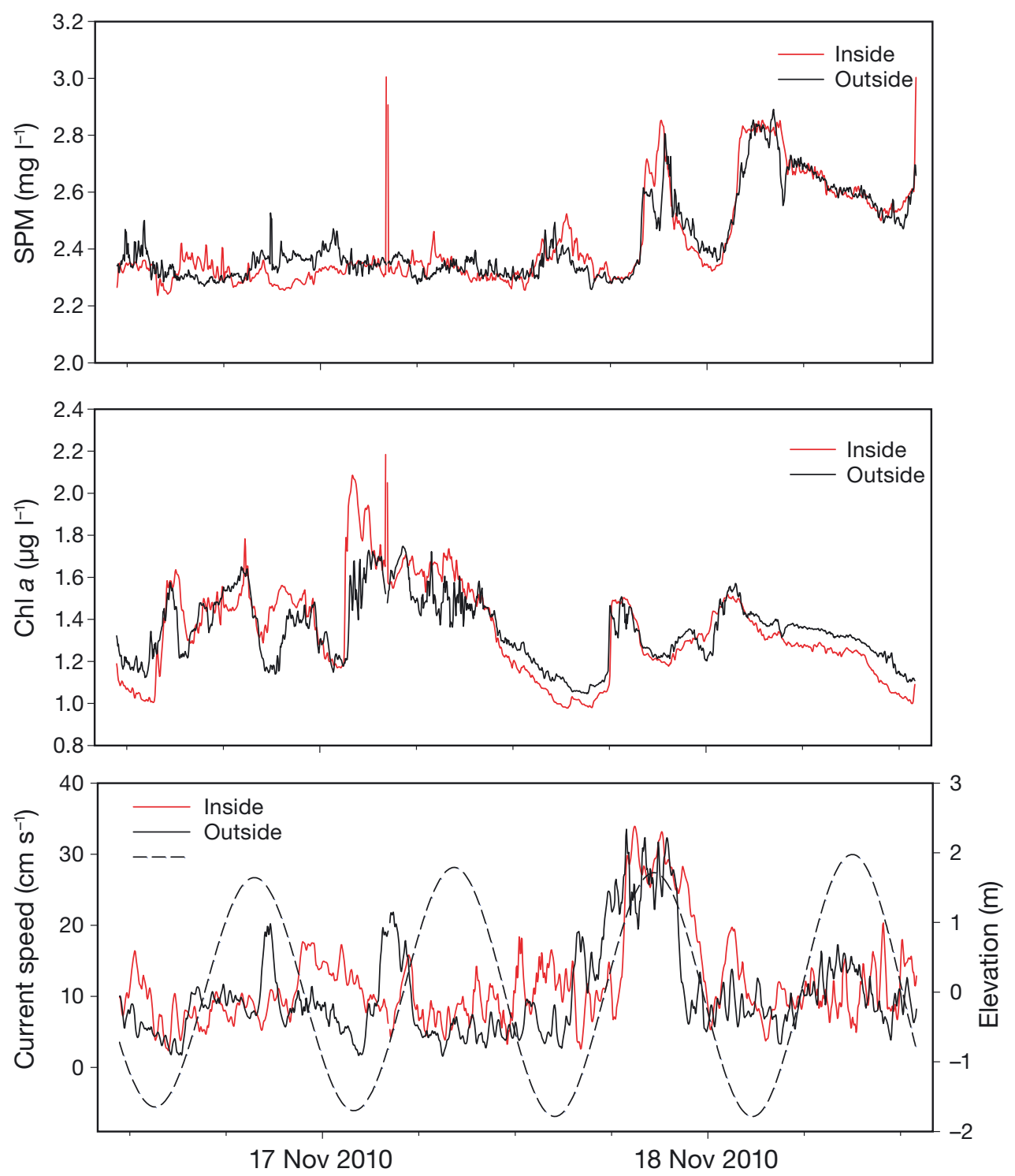

Fig. 2. Suspended particulate matter (SPM) and chlorophyll a (chl a) concentrations and current speeds, collected at 2 min intervals at $5 \mathrm{~m}$ depth, at the Navy Islands salmon farm. Data are from the 'inside' and 'outside' stations shown in Fig. 1. All instruments were located within $3 \mathrm{~m}$ of a net-pen. The dashed line is the predicted tidal elevation

in both SPM and chl a that corresponded to a periodicity of 12.2 to $12.7 \mathrm{~h}$ (Fig. 3). SPM was higher at $15 \mathrm{~m}$ depth $\left(4.2 \pm 0.5 \mathrm{mg} \mathrm{l}^{-1}\right)$ compared with values measured at $5 \mathrm{~m}\left(3.4 \pm 0.3 \mathrm{mg} \mathrm{l}^{-1}\right)$, and SPM and $\mathrm{chl} a$ at both depths were not correlated $\left(\mathrm{r}^{2}<0.03\right)$. The current meter moored at $15 \mathrm{~m}$ depth stopped recording early, but changes in current speed and direction were similar for both depths during the period when both instruments were operating (Fig. 3). The predominant current directions at this site were $160^{\circ}$ during flood tide and $250^{\circ}$ on the ebb. ANOVA comparisons of SPM concentrations in water flowing from different directions (based on the $5 \mathrm{~m}$ depth cur- rent data) indicated a significant effect of current direction on mean SPM concentrations at both depths. However, the Tukey comparisons did not indicate a significant enhancement of SPM in water flowing from the direction of the salmon net-pens (Table 3).

Currents at the Kyuquot Sound farm were generally slower than measured at the other farm sites and were dominated by flows to the southwest on both flood and ebb tides. Mean SPM concentrations were greater at $1 \mathrm{~m}$ depth $\left(2.7 \pm 0.9 \mathrm{mg} \mathrm{l}^{-1}\right)$ than at $20 \mathrm{~m}$ $\left(2.0 \pm 0.1 \mathrm{mg} \mathrm{l}^{-1}\right)$, and SPM and chl a values were poorly correlated at both depths $\left(\mathrm{r}^{2}<0.25\right)$. SPM lev- 

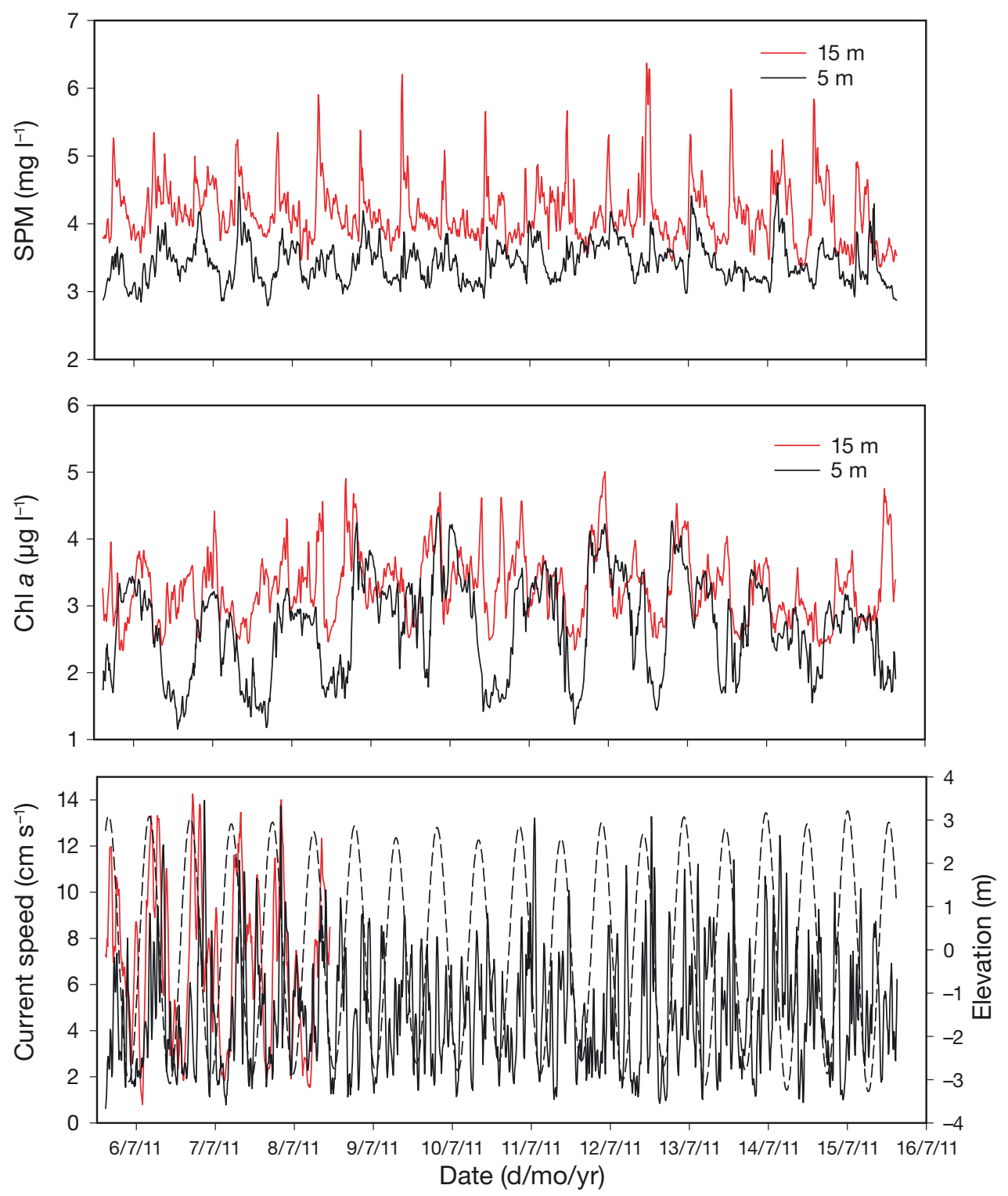

Fig. 3. Suspended particulate matter (SPM) and chlorophyll a (chl a) concentrations and current speeds, collected at 10 min intervals, at the Charlie Cove salmon farm. Data are from 5 and $15 \mathrm{~m}$ depths at a single mooring located $20 \mathrm{~m}$ from a net-pen (Fig. 1). The dashed line is the predicted tidal elevation. The instrument mooring was $20 \mathrm{~m}$ from the nearest salmon cage

els exhibited strong periodicity at $12.1 \mathrm{~h}$ and between 22 and $26 \mathrm{~h}$. The periods of elevated SPM at $1 \mathrm{~m}$ depth (Fig. 4) corresponded with periods when water was flowing from the southeast. ANOVA comparisons indicated significant directional changes in mean SPM concentrations at both depths, but that there was no significant SPM enhancement during periods when water was flowing from the direction of the net-pens (Table 3).

Currents measured at $5 \mathrm{~m}$ depth adjacent to the Flåtegrunnen salmon farm were strongly bidirectional, with predominant flow directions during flood and ebb tides at $105^{\circ}$ and $255^{\circ}$, respectively (Fig. 1). SPM concentrations measured at $5 \mathrm{~m}$ depth at the farm and reference locations (Fig. 5) were lower than measured at the 3 Canadian farms and were correlated with chl a concentrations (Fig. 6). SPM and chl $a$ levels at the farm and reference sites showed similar temporal variability, with slightly higher SPM concentrations measured at the farm mooring (Fig. 5). Spectral analysis of these data was not conducted owing to the relatively short sampling period. ANOVA comparisons showed no significant differences in mean SPM levels in water flowing to and 

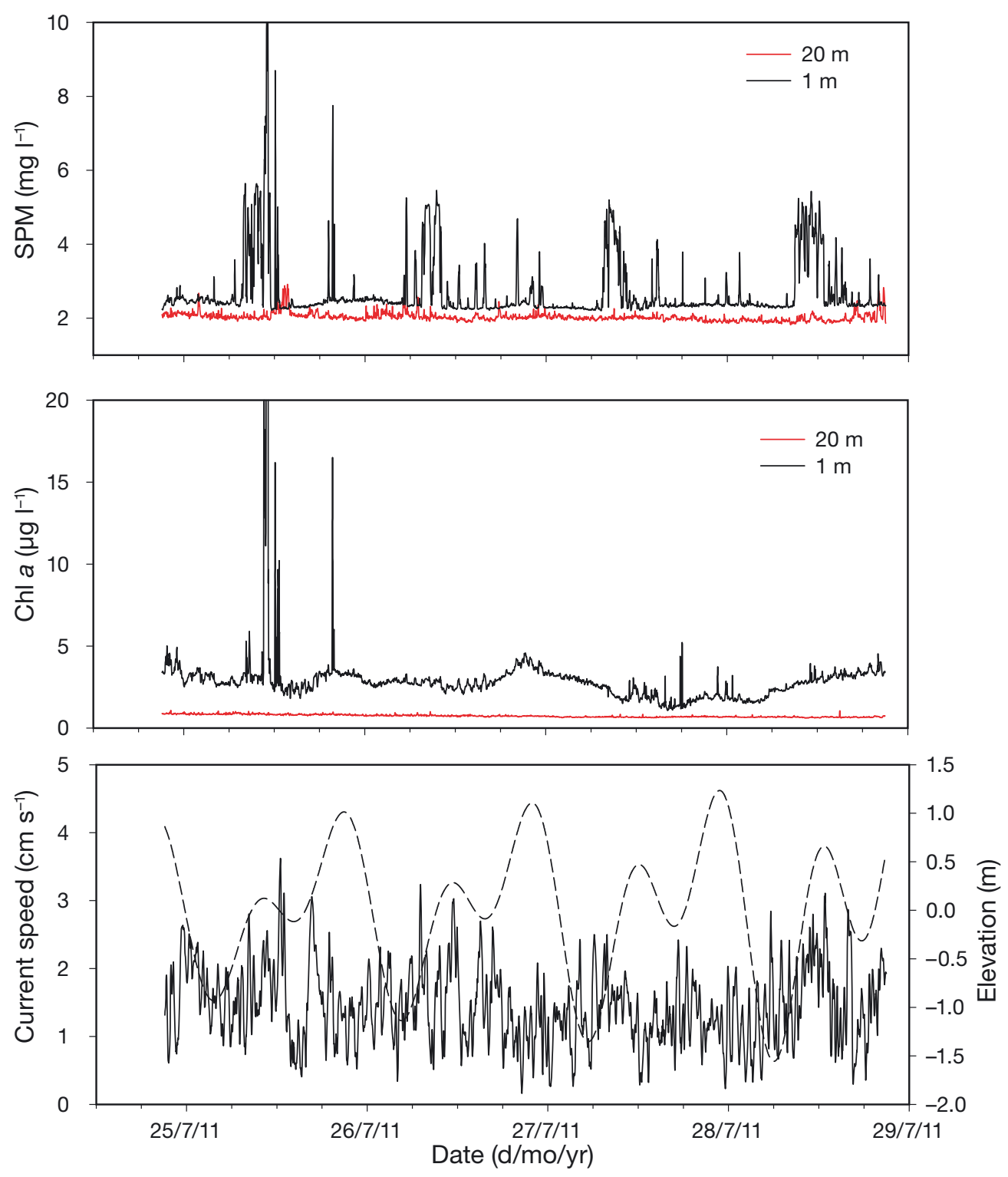

Fig. 4. Suspended particulate matter (SPM) and chlorophyll a (chl a) concentrations and current speeds, collected at 1 min intervals, at the Kyuquot Sound black cod farm. Data are from 1 and $20 \mathrm{~m}$ depths (19 $\mathrm{m}$ for current speed) at a mooring located $1 \mathrm{~m}$ from a net-pen (Fig. 1). The dashed line is the predicted tidal elevation

from the farm (i.e. no significant direction effect), but detected a significant difference in SPM concentrations at the farm site compared with the reference site (Table 3). The correlation between SPM and $\mathrm{chl} a$ at the farm site was lower than for the reference site (Fig. 6).

Calculations of the mean increase in SPM concentrations at each mooring location, assumed to originate from the addition of particulate farm wastes, are given in Table 3 . In all cases, the degree of particle enhancement was small ( 0.01 to $\left.0.24 \mathrm{mg} \mathrm{l}^{-1}\right)$. The only significant level of waste enhancement was de- tected for the mooring located $50 \mathrm{~m}$ away from for the Flåtegrunnen salmon farm (Table 1). The mean increase in SPM at this site, compared with the reference site, was $0.02 \mathrm{mg} \mathrm{l}^{-1}$.

\section{Time-series profiling}

Time-series contour plots of chl $a$ and SPM concentrations in the water column beside the Rataran salmon pen are shown in Fig. 7. During the $85 \mathrm{~min}$ sampling period, a total of 25 profiles (from 0.5 to 

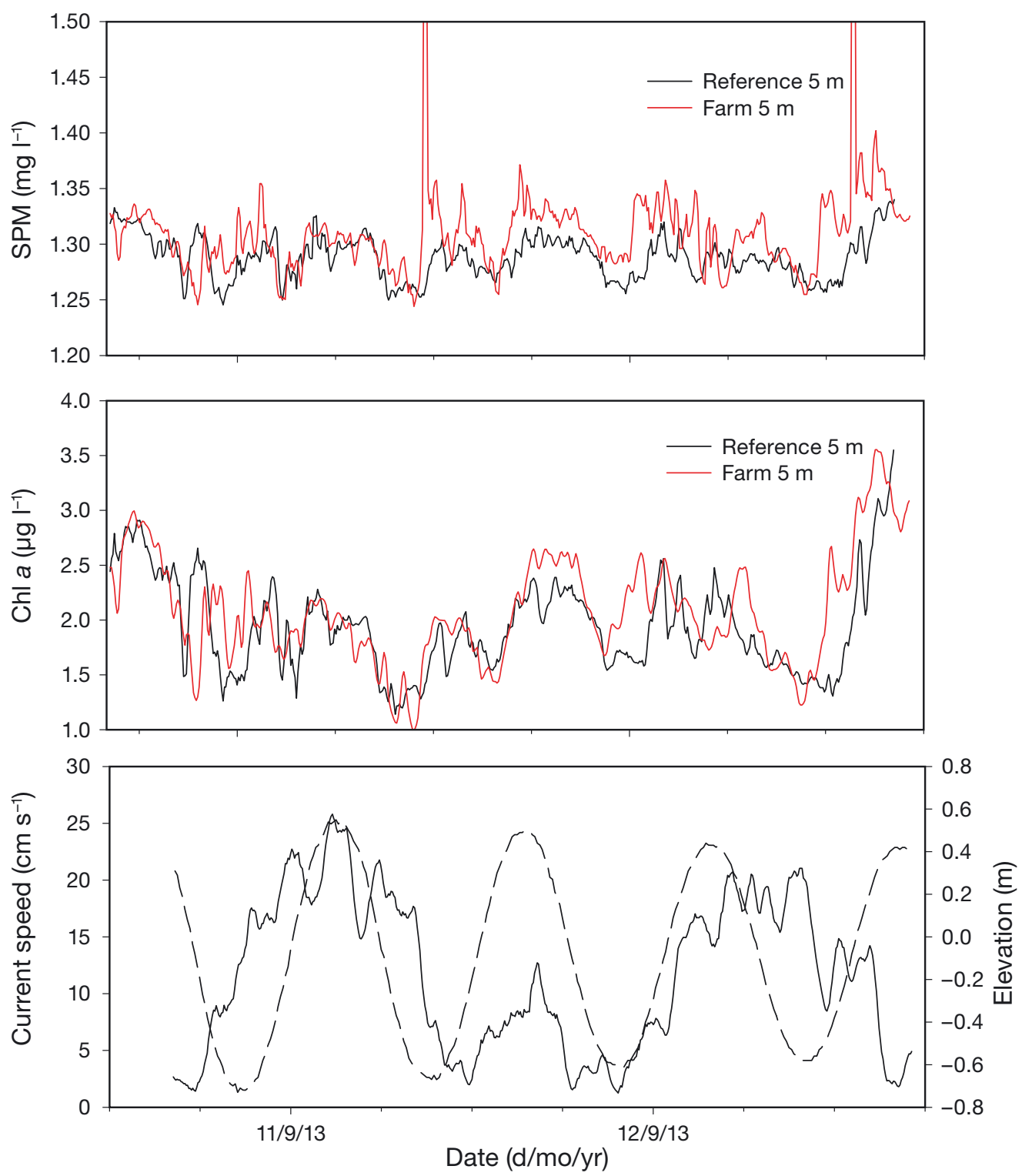

Fig. 5. Suspended particulate matter (SPM) and chlorophyll a (chl a) concentrations and current speeds, collected at 5 min intervals at a depth of $5 \mathrm{~m}$, at the farm (20 $\mathrm{m}$ from nearest salmon cage) and reference stations at the Flåtegrunnen salmon farm

(Fig. 1). The dashed line is the measured tidal elevation

$30 \mathrm{~m}$ depth) were conducted. The water depth at the profiling location was $40 \mathrm{~m}$. A chl a maximum was observed between 8 and $15 \mathrm{~m}$ depth and was observed to move upward during the sampling period (Fig. 7) in a manner similar to that of the pycnocline (data not shown). SPM concentrations were highest near the surface and generally declined with depth. However, particle concentrations below $25 \mathrm{~m}$ depth occasionally increased above a background level of approximately $1.9 \mathrm{mg} \mathrm{l}^{-1}$ (Fig. 7). The relationship between chl a and SPM concentrations at this site (Fig. 8) was more complex than for the Flåtegrunnen farm (Fig. 6). SPM in surface water (0 to $10 \mathrm{~m}$ depth) was negatively related with chl a levels, while the opposite trend was observed for deeper water. Water between 25 and $30 \mathrm{~m}$ depth generally contained relatively low SPM and chl a levels, but SPM occasionally increased by as much as $1 \mathrm{mg} \mathrm{l}^{-1}$ (Fig. 8). Current meter data collected to the southwest of the farm indicated a highly unidirectional flow (averaged $33^{\circ}$ between 4 and 15 August 2014) towards the farm on both flood and ebb tides (Fig. 1). During the sampling period, the mean direction was $30.9^{\circ}\left(\mathrm{SD}=7.5^{\circ}\right)$, with a mean current speed of $10.3 \mathrm{~m} \mathrm{~s}^{-1}\left(\mathrm{SD}=3.9 \mathrm{~m} \mathrm{~s}^{-1}\right)$. 
Table 3. Summary of ANOVA results comparing mean suspended particulate matter concentrations with current direction (12 direction levels representing 30 degree increments) or between farm and reference locations (Flåtegrunnen farm only). Significant ANOVA results (in bold) for the direction comparisons were followed by a single Tukey post hoc test comparing mean suspended particulate matter (SPM) values in the 2 direction bins that represent water flowing directly towards and away from the closest net-pen. The mean SPM enhancement at the mooring site was calculated from these 2 mean values

\begin{tabular}{|c|c|c|c|c|c|c|}
\hline Location & Source & df & Mean squares & $F$-ratio & $\mathrm{p}$-value & $\begin{array}{c}\text { Mean enhancement } \\
\left(\mathrm{mg} \mathrm{l}^{-1}\right)\end{array}$ \\
\hline Navy Islands Inside & $\begin{array}{l}\text { Direction } \\
\text { Error } \\
\text { Tukey }\end{array}$ & $\begin{array}{c}11 \\
1362\end{array}$ & $\begin{array}{l}0.399 \\
0.024\end{array}$ & 16.888 & $\begin{array}{c}<\mathbf{0 . 0 0 1} \\
0.072\end{array}$ & -0.29 \\
\hline Navy Islands Outside & $\begin{array}{l}\text { Direction } \\
\text { Error } \\
\text { Tukey }\end{array}$ & $\begin{array}{c}11 \\
1363\end{array}$ & $\begin{array}{c}0.227 \\
0.02\end{array}$ & 11.318 & $\begin{array}{c}<\mathbf{0 . 0 0 1} \\
0.052\end{array}$ & 0.05 \\
\hline Charlie Cove $5 \mathrm{~m}$ & $\begin{array}{l}\text { Direction } \\
\text { Error } \\
\text { Tukey }\end{array}$ & $\begin{array}{c}11 \\
1535\end{array}$ & $\begin{array}{l}0.403 \\
0.099\end{array}$ & 4.082 & $\begin{array}{r}<\mathbf{0 . 0 0 1} \\
1.000\end{array}$ & 0.04 \\
\hline Charlie Cove $15 \mathrm{~m}$ & $\begin{array}{l}\text { Direction } \\
\text { Error } \\
\text { Tukey }\end{array}$ & $\begin{array}{c}11 \\
1535\end{array}$ & $\begin{array}{l}1.108 \\
0.228\end{array}$ & 4.855 & $\begin{array}{r}<\mathbf{0 . 0 0 1} \\
1.000\end{array}$ & 0.05 \\
\hline Kyuquot Sound $1 \mathrm{~m}$ & $\begin{array}{l}\text { Direction } \\
\text { Error } \\
\text { Tukey }\end{array}$ & $\begin{array}{c}11 \\
4302\end{array}$ & $\begin{array}{l}2.459 \\
0.728\end{array}$ & 44.559 & $\begin{array}{r}<\mathbf{0 . 0 0 1} \\
0.096\end{array}$ & 0.24 \\
\hline Kyuquot Sound $20 \mathrm{~m}$ & $\begin{array}{l}\text { Direction } \\
\text { Error } \\
\text { Tukey }\end{array}$ & $\begin{array}{c}11 \\
4302\end{array}$ & $\begin{array}{l}0.407 \\
0.015\end{array}$ & 26.846 & $\begin{array}{r}<\mathbf{0 . 0 0 1} \\
1.000\end{array}$ & 0.02 \\
\hline Flåtegrunnen Farm & $\begin{array}{l}\text { Direction } \\
\text { Error } \\
\text { Tukey }\end{array}$ & $\begin{array}{c}11 \\
555\end{array}$ & $\begin{array}{l}0.002 \\
0.003\end{array}$ & 0.643 & $\begin{array}{c}0.792 \\
-\end{array}$ & 0.01 \\
\hline Flåtegrunnen Reference & $\begin{array}{l}\text { Direction } \\
\text { Error } \\
\text { Tukey }\end{array}$ & $\begin{array}{c}11 \\
538\end{array}$ & $\begin{array}{c}0.003 \\
0\end{array}$ & 8.54 & $\begin{array}{r}<\mathbf{0 . 0 0 1} \\
0.917\end{array}$ & 0.01 \\
\hline Flåtegrunnen & Location & 1 & 0.142 & 73.895 & $<0.001$ & 0.02 \\
\hline Farm versus reference & Error & 1114 & 0.002 & & & \\
\hline
\end{tabular}

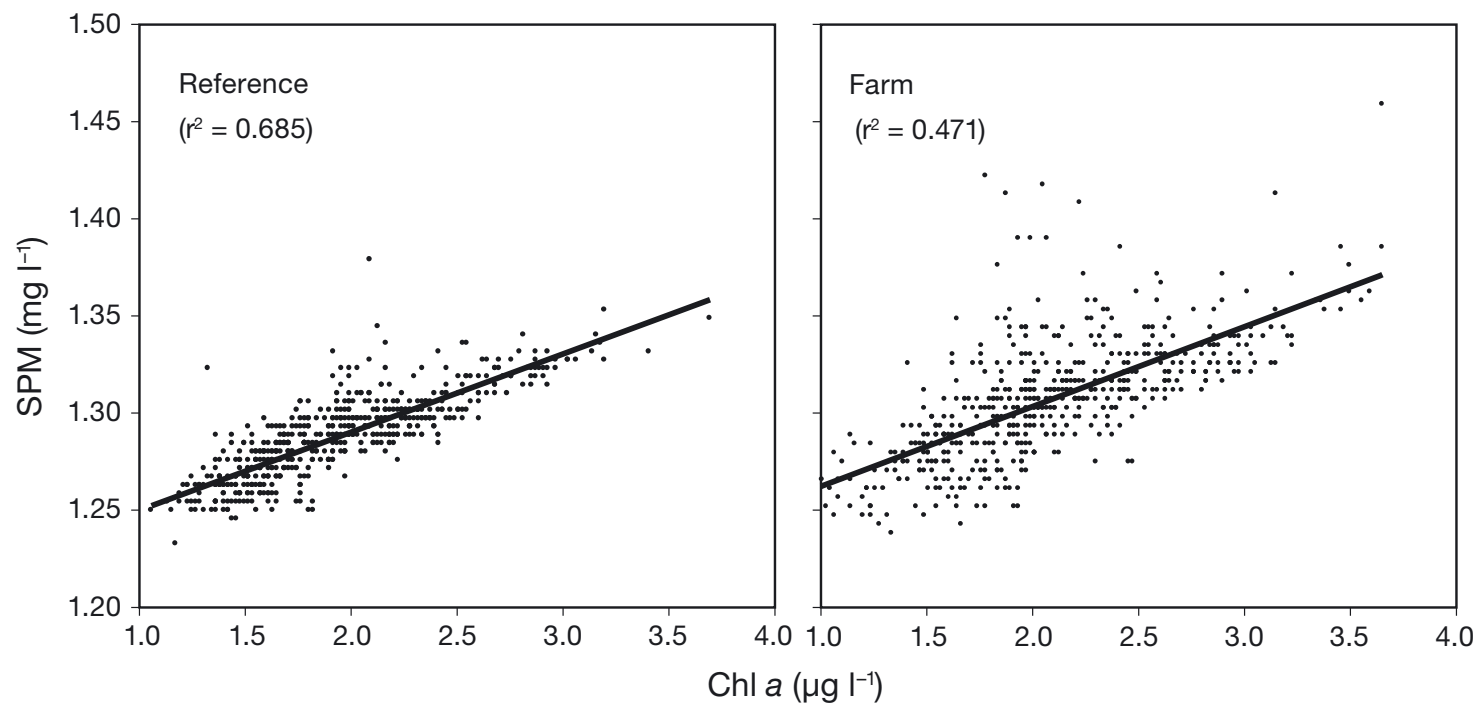

Fig. 6. Relationships between chlorophyll a ( $\mathrm{chl}$ a) and suspended particulate matter (SPM) concentrations at $5 \mathrm{~m}$ depth at the Flåtegrunnen farm and reference stations (Fig. 1) 

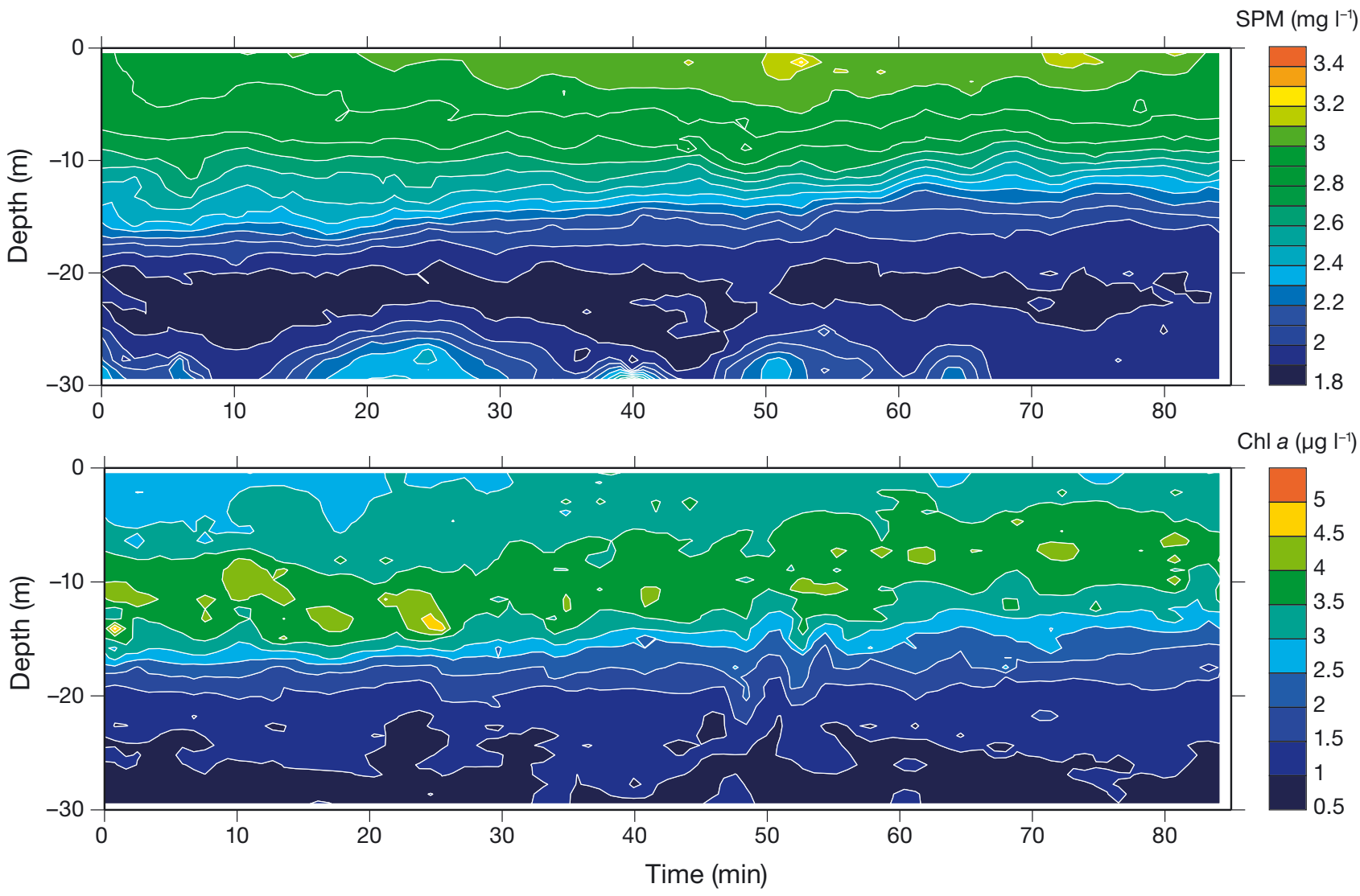

Fig. 7. Time-series contour plots of total suspended particulate matter (SPM) and chlorophyll a (chl a) concentrations in the water column at $2 \mathrm{~m}$ distance from a salmon net-pen on the outflow side of the Rataran farm (Fig. 1). The plots are based on in situ sensor profiles from 0.5 to $30 \mathrm{~m}$ depth, conducted at 3 min intervals, starting at 13:38 h on 6 August 2014

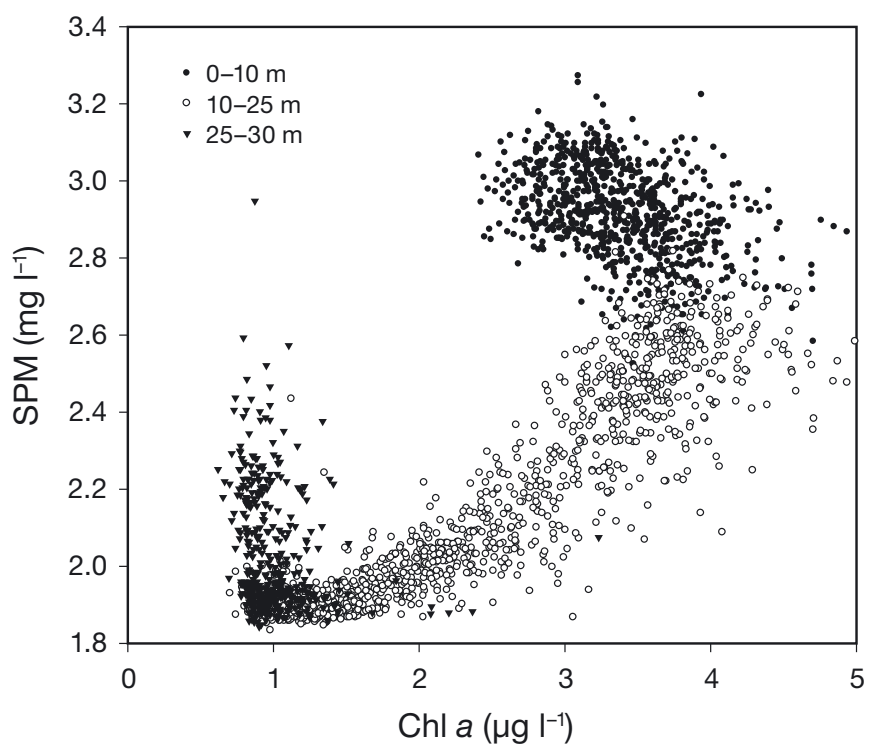

Fig. 8. Relationships between chlorophyll a ( $\mathrm{chl}$ a) and suspended particulate matter (SPM) concentrations over 3 depth ranges beside a salmon net-pen at the Rataran farm

\section{DISCUSSION}

Studies on SPM loading from open-water fish farms have not previously examined whether there is any persistent enhancement of the ambient seston in estuarine/coastal systems. The results of the present study showed the dynamic nature of the seston around 5 coastal fish farms, and demonstrate that fish farming has an overall negligible effect on SPM concentrations in the vicinity of the farms. These conclusions are based on periodogram power spectral density estimates, statistical comparisons of mean SPM levels flowing to and from the direction of net-pens, and comparisons between farm and reference sites. Temporal fluctuations in SPM levels at the study sites predominantly corresponded with tidal constituents. Frequency peaks corresponding to the M2 principal lunar semi-diurnal tidal constituent $(12.4 \mathrm{~h})$ were evident in the SPM time series collected in this investigation. The Kyuquot Sound data from $1 \mathrm{~m}$ depth also indicated a strong $24 \mathrm{~h}$ cycle (i.e. P1 principal solar 
diurnal tide). In tidally driven environments, variability of SPM concentration at tidal frequencies has been well documented (Cloern et al. 1989, Velegrakis et al. 1997, McCandliss et al. 2002). Previous studies have identified horizontal SPM concentration gradients along the tidal excursion (Weeks et al. 1993, Velegrakis et al. 1997) that will result in tidal cycle SPM variations at a given location. In the macro-tidal Passamaquoddy Bay, the tides have a significant effect on the seston (Dowd 2003). Although tidal advection has often been characterized as the predominant mechanism for short-term variability of SPM, other mechanisms (e.g. river sources, terrestrial inputs, wind, anthropogenic impacts) contribute to SPM variability observed at the tidal time scale (Fegley et al. 1992, Velegrakis et al. 1999, McCandliss et al. 2002, Shi 2010, Strohmeier et al. 2015). The recurring peaks in SPM concentrations at $1 \mathrm{~m}$ depth at the Kyuquot Sound mooring corresponded with periods when the predominantly southwest currents briefly switch to the southeast. This current direction indicates a terrestrial source of particles from a stream located to the west of the farm.

The companion study by Brager et al. (2015) concluded that the export of fish wastes from farms was highly localized and episodic. Consequently, it is important to consider the possible consequences of this spatial variability on the capacity of the present study to detect the presence of particulate wastes. The analysis of the particle sensor data focused specifically on periods when the current was flowing from the nearest net-pen towards the particle sensors. This approach was taken specifically to minimize the importance of the geographic location and the limited number of sensor moorings deployed. Based on this approach, the probability of missing waste discharges at all 5 farm sites is believed to be extremely low. The high sampling frequency of electronic particle sensors allows for the collection of large sample sizes and, consequently, results in high statistical power to detect small differences between temporal data sets. Hypothesis testing provided no indication of a significant increase in mean SPM levels at any of the farms during periods when water was flowing to the sensors from the direction of the net-pen. The only indication of particle enhancement from a fish farm was for Flåtegrunnen, where SPM levels at $5 \mathrm{~m}$ depth near the farm were found to be significantly different than for the reference site located $1 \mathrm{~km}$ away. However, the mean level of SPM enhancement at this site was only $0.02 \mathrm{mg} \mathrm{l}^{-1}$. Given that the precision of the ECOmeter SPM calibration was approximately $0.3 \mathrm{mg} \mathrm{SPM} \mathrm{l}^{-1}$ (standard error of estimate, Table 2), the actual degree of seston enhancement at this farm cannot be accurately quantified other than to state that the contribution of fish wastes to the natural particle field was very low. The detection of such a small anthropogenic effect at the Flåtegrunnen farm was facilitated by the low seston conditions and dominance of phytoplankton over non-living particulate matter in this oligotrophic fjord (Fig. 6).

Water column profiling with particle sensors allows for greater depth coverage that can be achieved with moored instruments, albeit with a reduced sampling period. Continuous profiling immediately adjacent to the Rataran salmon pen on 6 August 2014 detected relatively high SPM levels, compared with chl $a_{\text {, in }}$ the $0.5-10 \mathrm{~m}$ and $25-30 \mathrm{~m}$ depth ranges. During sampling, the current was flowing from the direction of a net-pen that contained harvest-sized salmon that were actively feeding. The elevated SPM levels in the upper water column appear to occur naturally, as opposed to resulting from the presence of fish feed 'fines', and may consist of detrital material from the abundant macrophyte beds in this region. Spatial sampling around this farm showed a similar vertical distribution of SPM in the upper water column regardless of the profiling location (data not shown). SPM levels in the 25-30 m depth range occasionally increased by as much as $1.0 \mathrm{mg} \mathrm{l}^{-1}$ above the background concentration. This layer is below the depth of the salmon pen and the periodic increases in SPM likely indicate from the presence of salmon faeces.

The presence of finfish aquaculture sites has previously been predicted and shown to impact the surrounding suspended particle field. Troell \& Norberg (1998) calculated that farm waste production, including uneaten whole feed pellets, feed 'fines' and faecal wastes, could increase suspended solids concentrations inside a fish cage anywhere from 3- to 30 -fold. That study assumed $10 \%$ feed wastage. Early estimates of feed loss were approximately $20 \%$ (Beveridge 1987), but have since been reduced through improved feeding control mechanisms (Reid et al. 2009). The most recent feed wastage estimates are below $5 \%$ (Cromey et al. 2002, Perez et al. 2002, Strain \& Hargrave 2005, Stucchi et al. 2005). Waste concentrations exiting the cages will rapidly decline through dilution and the rapid sedimentation of feed pellets and faeces (Troell \& Norberg 1998). MacDonald et al. (2011) reported significantly elevated SPM concentrations at $2 \mathrm{~m}$ depth within 3 salmon farms in the Bay of Fundy, including the Charlie Cove farm studied herein. However, Brager et al. (2015) concluded from extensive spatial sampling that any farm-induced effect on the surrounding particle field 
would be highly localized and episodic. This is consistent with the results of Lander et al. (2013), who reported elevated SPM levels at $5 \mathrm{~m}$ depth inside the Charlie Cove salmon cages during sampling in 2004, but only during salmon feeding periods. These authors reported that waste concentrations dropped to ambient levels between 5 and $10 \mathrm{~m}$ distance from the cage. These conclusions are consistent with results from the present study that showed a lack of a waste particle signal at $20 \mathrm{~m}$ from this farm, and the extremely low waste signal detected $50 \mathrm{~m}$ away from the Flåtegrunnen farm. However, sampling within $2 \mathrm{~m}$ of fish pens at the Navy Islands, Kyuquot Sound and Rataran farms did not detect a significant increase in fish wastes in the water column. The latter farm was the largest salmon farm studied and sampling was conducted continuously over an $85 \mathrm{~min}$ period as feed was being pumped into the cage at approximately 0.5 tonnes $\mathrm{h}^{-1}$. Faecal matter appeared to be intermittently present in the lower water column, but SPM levels beside the pen remained at ambient concentrations. This indicates that feed wastage at this farm was very low. Water profiling with SPM sensors inside a Kyuquot Sound fish pen before, during and after feeding also showed no increase in SPM from the addition of feed 'fines' (Brager et al. 2015). Feed is the highest single cost in salmon farming, and maximizing utilization and minimizing loss due to pellet breakage and dust formation strongly motivates continued progress in the formulation of food pellets. Improvements over the past decade in pellet durability during transport at the fish farm and stability in water may have contributed to the low degree of feed wastage detected in the present study.

The stimulus for the present study on the temporal dynamics of particulate wastes at coastal fish farms, as well as the companion study on spatial dynamics (Brager et al. 2015), was the desire to optimize interactions between fish wastes and extractive species in IMTA systems (see Introduction). The IMTA concept strives to increase global food production and reduce environmental impacts from intensive fish culture. Bivalve culture has been the primary focus of studies on particulate waste extraction in IMTA systems. However, the results of the present study, along with those from other studies, provide a weight of evidence against the practical incorporation of commercial bivalve operations in IMTA systems. In brief, SPM and bivalve growth enhancement in waters around fish farms tend to be absent, miniscule or highly localized (see above), and model predictions of fish waste capture efficiency by bivalve populations in IMTA systems are low owing to the limited time available for the bivalves to intercept wastes in the horizontal particle flux (Cranford et al. 2013). The establishment of commercial-scale bivalve culture at fish farms requires strong evidence of a persistent and elevated food supply over a scale sufficient for the bivalves to effectively capture the wastes. Previous observations that fish wastes can comprise an important fraction of the bivalve diet have been limited to areas with low seston concentrations and organic content, inside or very close to net-pens and/or during winter, when natural food is relatively scarce (reviewed in Cranford et al. 2013). Although the intensive salmon farming operations at the Rataran and Flåtegrunen sites take place within oligotrophic environments, the presence of a consistent and significantly elevated supply of waste particles to help support bivalve co-culture was not supported by the results of the present study. Environmental concerns regarding the discharge of particulate fish wastes are directed primarily at the benthic habitat and community effects that stem from the rapid deposition of unused feed pellets and faeces below the net-pens (e.g. Bannister et al. 2016). Even if some faeces were to reach bivalves held beside the pens, this material does not appear to be effectively utilized (Handå et al. 2012b), and any benefit may be negated by faeces deposition by the bivalves themselves (Cranford et al. 2013). Future open-water IMTA research should focus on the development of systems that rely on extractive species held below fish cages.

Acknowledgements. This work was supported by the Department of Fisheries and Oceans Canada through contributions to the strategic Canadian Integrated MultiTrophic Aquaculture Network (CIMTAN), and the Norwegian Research Council trough funding of the ERA (Environmental responses to organic and inorganic effluents from fin-fish aquaculture; project no. 228871) and EXPLOIT (Exploitation of nutrients from salmon aquaculture; project no. 216201) projects. The authors thank Drs. Jon Grant, Shawn Robinson, Steve Cross, Raymond Bannister, Paul Hill and Mike Dowd for their many contributions, advice and assistance throughout this project.

\section{LITERATURE CITED}

Bannister RJ, Johnsen IA, Kupka-Hansen P, Kutti T, Asplin L (in press) (2016) Near- and far-field dispersal modelling of organic waste from Atlantic salmon aquaculture in fjord systems. ICES J Mar Sci doi:10.1093/icesjms/fsw027

Beveridge MCM (1984) Cage aquaculture. Blackwell Science, Oxford

Beveridge MCM (1987) Cage aquaculture. Blackwell Science, Oxford

Beveridge MCM, Phillips MJ, Clarke RM (1991) A quantita- 
tive and qualitative assessment of wastes from aquatic animal production. In: Brune D, Tomasso JR (eds) Aquaculture and water quality. Advances in world aquaculture 3. The World Aquaculture Society, Baton Rouge, LA, p 506-533

Beveridge MCM, Ross GL, Kelly AL (1994) Aquaculture and biodiversity. Ambio 23:497-502

> Brager LM, Cranford PJ, Grant J, Robinson SMC (2015) Spatial distribution of suspended particulate wastes at openwater Atlantic salmon and sablefish aquaculture farms in Canada. Aquacult Environ Interact 6:135-149

Buschmann A, Troell M, Kautsky N, Kautsky L (1996) Integrated tank cultivation of salmonids and Gracilaria chilensis (Gracilariales, Rhodophyta). Hydrobiologia 326:75-82

Cheshuk BW, Purser GJ, Quintana R (2003) Integrated openwater mussel (Mytilus planulatus) and Atlantic salmon (Salmo salar) culture in Tasmania, Australia. Aquaculture 218:357-378

> Chopin T, Buschmann AH, Halling C, Troell M and others (2001) Integrating seaweeds into marine aquaculture systems: a key towards sustainability. J Phycol 37:975-986

> Cloern JE, Powell TM, Huzzey LM (1989) Spatial and temporal variability in South San Francisco Bay II. Temporal changes in salinity, suspended sediments, and phytoplankton biomass and productivity over tidal time scales. Estuar Coast Shelf Sci 28:599-613

> Cranford PJ, Reid GK, Robinson SMC (2013) Open water integrated multi-trophic aquaculture: constraints on the effectiveness of mussels as an organic extractive component. Aquacult Environ Interact 4:163-173

> Cromey CJ, Nickell TD, Black KD (2002) DEPOMOD modeling the deposition and biological effects of waste solids from marine cage farms. Aquaculture 214:211-239

Dowd M (2003) Seston dynamics in a tidal inlet with shellfish aquaculture: a model study using tracer equations. Estuar Coast Shelf Sci 57:523-537

Fang JG, Sun HL, Yan JP, Kuang SH, Li F, Newkirk G, Grant J (1996) Polyculture of scallop Chlamys farreri and kelp Laminaria japonica in Sungo Bay. Chin J Oceanology Limnol 14:322-329

FAO (2012) The state of world fisheries and aquaculture 2012. FAO, Rome

Fegley SR, MacDonald BA, Jacobsen TR (1992) Short-term variations in the quantity and quality of seston available to benthic suspension feeders. Estuar Coast Shelf Sci 34: 393-412

Folke C, Kautsky N (1989) The role of ecosystems for a sustainable development of aquaculture. Ambio 18:234-243

Gowen RJ, Bradbury NB (1987) The ecological impact of salmonid farming in coastal waters: a review. Oceanogr Mar Biol Annu Rev 25:563-575

Gryska A, Parsons J, Shumway SE, Geib K, Emery I, Kuenster S (1996) Polyculture of sea scallops suspended from salmon cages. J Shellfish Res 15:481 (Summary)

> Handå A, Min H, Wang X, Broch OJ, Reitan KI, Helge R, Olsen Y (2012a) Incorporation of fish feed and growth of blue mussels (Mytilus edulis) in close proximity to salmon (Salmo salar) aquaculture: implications for integrated multi-trophic aquaculture in Norwegian coastal waters. Aquaculture 356-357:328-341

Handå A, Ranheim A, Olsen AJ, Altin D, Reitan KI, Olsen Y, Reinertsen H (2012b) Incorporation of salmon fish feed and feces components in mussels (Mytilus edulis): implications for integrated multi-trophic aquaculture in Nor- wegian coastal waters. Aquaculture 370-371:40-53

Jiang Z, Wang G, Fang J, Mao Y (2013) Growth and food sources of Pacific oyster Crassostrea gigas integrated culture with sea bass Lateolabrax japonicus in Ailian Bay, China. Aquacult Int 21:45-52

Jones TO, Iwama GK (1991) Polyculture of the Pacific oyster, Crassostrea gigas (Thunberg), with Chinook salmon, Oncorhynchus tshawytscha. Aquaculture 92:313-322

Kutti T, Hansen PK, Ervik A, Høisæter T, Johannessen P (2007) Effects of organic effluents from a salmon farm on a fjord system. II. Temporal and spatial patterns in infauna community composition. Aquaculture 262:355-366

Lander T, Barrington K, Robinson S, MacDonald B, Martin J (2004) Dynamics of the blue mussel as an extractive organism in an integrated aquaculture system. Bull Aquacult Assoc Can 104:19-28

Lander TR, Robinson SMC, MacDonald BA, Martin JD (2012) Enhanced growth rates and condition index of blue mussels (Mytilus edulis) held at integrated multitrophic aquaculture (IMTA) sites in the Bay of Fundy. J Shellfish Res 31:997-1007

> Lander TR, Robinson SMC, MacDonald BA, Martin JD (2013) Characterization of the suspended organic particles released from salmon farms and their potential as a food supply for the suspension feeder, Mytilus edulis in integrated multi-trophic aquaculture (IMTA) systems. Aquaculture 406-407:160-171

> Lefebvre S, Barille L, Clerc M (2000) Pacific oyster (Crassostrea gigas) feeding responses to a fish-farm effluent. Aquaculture 187:185-198

Li S (1987) Energy structure and efficiency of a typical Chinese integrated fish farm. Aquaculture 65:105-118

> MacDonald BA, Robinson SMC, Barrington KA (2011) Feeding activity of mussels (Mytilus edulis) held in the field at an integrated multi-trophic aquaculture (IMTA) site (Salmo salar) and exposed to fish food in the laboratory. Aquaculture 314:244-251

- McCandliss RR, Jones SE, Hearn M, Latter R, Jago CF (2002) Dynamics of suspended particles in coastal waters (southern North Sea) during a spring bloom. J Sea Res 47:285-302

Navarrete-Mier F, Sanz-Lazaro C, Marin A (2010) Does bivalve mollusc polyculture reduce marine fin fish farming environmental impact? Aquaculture 306:101-107

> Nickell TD, Cromey CJ, Borja A, Black KD (2009) The benthic impacts of a large cod farm - Are there indicators for environmental sustainability? Aquaculture 295:226-237

Olsen LM, Holmer M, Olsen Y (2008) Perspectives of nutrient emission from fish aquaculture in coastal waters: literature review with evaluated state of knowledge. Final report. Fishery and Aquaculture Industry Research Fund (FHF), Oslo

> Perez OM, Telfer TC, Beveridge MCM, Ross LG (2002) Geographical Information Systems (GIS) as a simple tool to aid modeling of particulate waste distribution at marine fish cage sites. Estuar Coast Shelf Sci 54:761-768

Phillips MJ, Beveridge MCM, Clarke RM (1991) Impact of aquaculture on water resources. In: Brune D, Tomasso JR (eds) Aquaculture and water quality. Advances in world aquaculture 3. The World Aquaculture Society, Baton Rouge, LA, p 568-591

Pridmore RD, Rutherford JC (1992) Modelling phytoplankton abundance in a small enclosed bay used for salmon farming. Aquacult Fish Manage 23:525-542

Qian PY, Wu CY, Wu M, Xie YK (1996) Integrated cultiva- 
tion of the red alga Kappaphycus alvarezii and the pearl oyster Pinctada martensi. Aquaculture 147:21-35

Reid GK, Liutkus M, Robinson SMC, Chopin TR and others (2009) A review of the biophysical properties of salmonid faeces: implications for aquaculture waste dispersal models and integrated multi-trophic aquaculture. Aquacult Res 40:257-273

Sarà G, Zenone A, Tomasello A (2009) Growth of Mytilus galloprovincialis (Mollusca bivalvia) close to fish farms: a case of integrated multi-trophic aquaculture in the Tyrrhenian sea. Hydrobiologia 636:129-136

Shi JZ (2010) Tidal resuspension and transport processes of fine sediment within the river plume in the partially mixed Changjiang River estuary, China: a personal perspective. Geomorphology 121:133-151

Soto D (2009) Integrated mariculture: a global review. FAO Fisheries and Aquaculture Technical Paper 529. FAO, Rome

Stirling HP, Okumus I (1995) Growth and production of mussels (Mytilus edulis L.) suspended at salmon cages and shellfish farms in two Scottish sea lochs. Aquaculture 134:193-210

Strain PM, Hargrave BT (2005) Salmon aquaculture, nutrient fluxes and ecosystem processes in southwestern New Brunswick. In: Hargrave BT (ed) Environmental effects of marine finfish aquaculture. Springer, Berlin, p 29-57

Strohmeier T, Strand Ø, Alunno-Bruscia M, Duinker A and others (2015) Response of Mytilus edulis to enhanced phytoplankton availability by controlled upwelling in an oligotrophic fjord. Mar Ecol Prog Ser 518:139-152

Stucchi D, Sutherland TA, Levings C, Higgs D (2005) Nearfield deposition model for salmon aquaculture waste. In: Hargrave BT (ed) Handbook of environmental chemistry 5, Part M. Springer-Verlag, Berlin, p 157-179

Sugiura SH, Marchant DD, Kelsey K, Wiggins T, Ferraris RP (2006) Effluent profile of commercially used low-phosphorus fish feeds. Environ Pollut 140:95-101

Taranger GL, Karlsen Ø, Bannister RJ, Glover KA and others (2015) Risk assessment of the environmental impact of Norwegian Atlantic salmon farming. ICES J Mar Sci 72:

Editorial responsibility: Catriona MacLeod, Hobart, Tasmania, Australia
997-1021

- Taylor BE, Jamieson G, Carefoot TH (1992) Mussel culture in British Columbia: the influence of salmon farms on growth of Mytilus edulis. Aquaculture 108:51-66

> Thompson KR, Dowd M, Shen Y, Greenberg DA (2002) Probabilistic characterization of tidal mixing in a coastal embayment: a Markov chain approach. Cont Shelf Res 22:1603-1614

Trites RW, Garrett CJR (1983) Physical oceanography of the Quoddy Region. Can Spec Publ Fish Aquat Sci 64:9-34

Troell M, Norberg J (1998) Modelling output and retention of suspended solids in an integrated salmon-mussel culture. Ecol Model 110:65-77

Troell M, Halling C, Neori A, Chopin T, Buschmann AH, Kautsky N, Yarish C (2003) Integrated mariculture: asking the right questions. Aquaculture 226:69-90

Troell M, Joyce A, Chopin T, Neori A, Buschmann AH, Fang JG (2009) Ecological engineering in aquaculturepotential for integrated multi-trophic aquaculture (IMTA) in marine offshore systems. Aquaculture 297:1-9

Valdemarsen TB, Bannister RJ, Hansen PK, Holmer M, Ervik A (2012) Biogeochemical malfunctioning in sediments beneath a deep-water fish farm. Environ Pollut 170:15-25

Velegrakis AF, Bishop C, Lafite R, Oikonomou EK, Lecouturier M, Collins MD (1997) Investigation of meso- and macro-scale sediment transport, hydrodynamics biogeochemical processes and fluxes in the channel. FLUXMANCHE II Final Report, MAST II:128-143

Velegrakis AF, Collins MD, Lafite MB, Oikonomou EK and others (1999) Sources, sinks and resuspension of suspended particulate matter in the eastern English Channel. Cont Shelf Res 19:1933-1957

> Weeks AR, Simpson JH, Bowers D (1993) The relationship between concentrations of suspended particulate material and tidal processes in the Irish Sea. Cont Shelf Res 13:1325-1334

> Whitmarsh DJ, Cook EJ, Black KD (2006) Searching for sustainability in aquaculture: an investigation into the economic prospects for an integrated salmon-mussel production system. Mar Policy 30:293-298

Submitted: April 18, 2016; Accepted: June 29, 2016 Proofs received from author(s): August 2, 2016 